\title{
Effect of 4-(4-Chlorobenzyl)pyridine on Rat Hepatic Microsomal Cytochrome P450 and Drug-Metabolizing Enzymes in Vivo and in Vitro
}

\author{
Yasuna Kobayashi, ${ }^{a}$ Naomi Ohshiro, ${ }^{a}$ Tadanori SAsaki,${ }^{a}$ Shogo Tokuyama, ${ }^{a}$ Takashi Tobe,${ }^{c}$ \\ Takemi Yoshida, ${ }^{b}$ and Toshinori Yамамото ${ }^{*, a}$ \\ Department of Clinical Pharmacy, ${ }^{a}$ Biochemical Toxicology, ${ }^{b}$ and Medicinal Information, ${ }^{c}$ School of Pharmaceutical \\ Sciences, Showa University, 1-5-8, Hatanodai, Shinagawa-ku, Tokyo 142-8555, Japan. \\ Received October 10, 2000; accepted January 24, 2001
}

The effect of 4-(4-chlorobenzyl)pyridine (4-CBP) on rat hepatic microsomal cytochrome P450 (P450) and its molecular species (CYP2B1, 2E1, 3A2, 2C11, and 2C12), and on drug-metabolizing enzyme activities were examined in vivo and in vitro. Treatment of rats with 4-CBP resulted in the induction of $\mathrm{P} 450$ and drug-metabolizing enzymes in a dose-dependent manner, but it was markedly inhibitory at higher dose levels. Immunoblot analyses revealed that 4-CBP induces both CYP2B1 and 2E1; however, both were decreased by increasing the dose of 4CBP. The in vitro inhibitory experiment revealed that 4-CBP strongly inhibited benzphetamine $N$-demethylase activity, but not dimethylnitrosamine $N$-demethylase activity. The present findings provide information on the induction and inhibition effect of chlorinated benzylpyridine on hepatic microsomal P450s and drug-metabolizing enzymes in vivo and in vitro.

Key words cytochrome P450; pyridine; 4-(4-chlorobenzyl)pyridine; enzyme induction

Cytochrome P450 (P450) enzymes are well known to be induced or inhibited by a broad spectrum of structurally unrelated compounds. ${ }^{1)}$ Many investigators have demonstrated that $N$-substituted imidazole-containing drugs and chemicals, such as clotrimazole and 1-benzylimidazole, are potent inducers of rat hepatic P450 and its associated mono-oxygenase activities. ${ }^{2-9)}$ To date, we have reported that compounds substituted at the 1- or 4-position of the imidazole- and pyridine-rings, respectively, are potent inducers of rat hepatic microsomal $\mathrm{P} 450$ in vivo, but these chemicals markedly inhibited P450-dependent mono-oxygenase activity when added in an in vitro assay system. ${ }^{10-14)}$ Recently, we reported that 2,2'-dipyridyl ketone induces both $\mathrm{P} 450$ and heme oxygenase activity, whereas 2,2'-dipyridyl and 2,2'-dipyridyl amine are able to increase heme oxygenase activity with a decreasing P450 content. ${ }^{12,15,16)}$ Thus, investigation of the effect of substituted heterocyclic aromatic compounds on drug metabolizing enzymes is of importance for determining drug toxicity.

We have shown that 4-benzylpyridine induces rat hepatic P450 and drug-metabolizing enzymes in a dose-dependent manner. ${ }^{10)}$ In addition, we reported that 4-phenylalkylpyridines induce $\mathrm{P} 450$ in a chain-length dependent manner, and inhibit drug-metabolizing enzyme activity when added in vitro to the assay medium. ${ }^{13)}$ 4-(4-Chlorobenzyl)pyridine (4-CBP) is one of these substituted pyridine derivatives with a chlorine atom at the 4 position of the benzyl moiety. There are many drugs and chemicals which have chlorine atom(s); however, the effects of chlorinated pyridines on hepatic P450 and drug-metabolizing enzymes are less well characterized. This paper describes the induction and inhibition of rat microsomal P450s and drug-metabolizing enzymes by 4-CBP, together with changes in various $\mathrm{P} 450$ species (CYP2B1, $2 \mathrm{E} 1,3 \mathrm{~A} 2,2 \mathrm{C} 11$, and $2 \mathrm{C} 12$ ) in male and female rat liver.

\section{MATERIALS AND METHODS}

Chemicals 4-CBP was purchased from Tokyo Kasei Co., Ltd. (Tokyo, Japan). The chemical purity of 4-CBP was
$>98 \%$. Anti-P450 antibodies (CYP2B1, 2E1, 3A2, 2C11) for immunoblot analysis were purchased from Daiichi Pure Chemicals Co., Ltd. (Tokyo, Japan). Anti-CYP2C12 antibody raised against P450 2C12 was kindly provided by Drs. Susumu Imaoka and Yoshihiko Funae, Laboratory of Chemistry, Osaka City University Medical School (Osaka, Japan). All other chemicals used were of the highest grade commercially available.

Animals and Treatment Male and female Wistar rats, weighing $180-220 \mathrm{~g}$, were used in this study and were fed a commercial solid diet (MF, Oriental Yeast, Tokyo, Japan) and water ad libitum. 4-CBP was suspended in an appropriate volume of corn oil $(1 \mathrm{ml} / \mathrm{kg})$ and injected intraperitoneally (i.p.) into rats at doses ranging from 0.10 to $0.80 \mathrm{mmol} / \mathrm{kg}$ for a single administration. Control rats were injected i.p. with the vehicle alone. All rats were fasted for $24 \mathrm{~h}$ before being killed.

Tissue Preparation Rats were killed by decapitation and their livers were immediately perfused in situ with ice-cold $0.9 \%(\mathrm{w} / \mathrm{v}) \mathrm{NaCl}$ solution. The livers were homogenized with 5 bed volumes of $1.15 \%(\mathrm{w} / \mathrm{v}) \mathrm{KCl}$ with a Potter-Elvehjem homogenizer with a Teflon pestle and the liver homogenate was centrifuged at $9000 \times \boldsymbol{g}$ for $20 \mathrm{~min}$. The resulting supernatant was then ultracentrifuged at $105000 \times \boldsymbol{g}$ for $1 \mathrm{~h}$. The resulting microsomal pellet was suspended in $10 \mathrm{~mm}$ Tris acetate buffer ( $\mathrm{pH} 7.4)$ containing $1 \mathrm{~mm}$ EDTA, 20\% (v/v) glycerol and $400 \mu \mathrm{M}$ PMSF (phenylmethylsulfonyl fluoride). The sample was used to determine total P450 content, aminopyrine $N$-demethylase and aniline $p$-hydroxylase activities, and also for immunoblot analysis. To determine the inhibitory effect of 4-CBP on drug-metabolizing enzyme activity in vitro, rats were treated i.p. with phenobarbital and pyridine at the dose of $80 \mathrm{mg} / \mathrm{kg}$ for $2 \mathrm{~d}$ and $100 \mathrm{mg} / \mathrm{kg}$ for $4 \mathrm{~d}$, respectively.

Enzyme Assays Hepatic microsomal cytochrome P450 content was determined from a carbon monoxide difference spectrum of dithionite-treated microsomes (about $2 \mathrm{mg}$ protein $/ \mathrm{ml}$ ) after they had been dissolved in a microsome solubilization buffer (100 mm potassium phosphate buffer ( $\mathrm{pH} 7.3)$, 
$0.5 \%(\mathrm{w} / \mathrm{v})$ sodium cholate, $1 \mathrm{~mm}$ EDTA, $20 \%(\mathrm{v} / \mathrm{v})$ glycerol, $0.4 \%(\mathrm{v} / \mathrm{v})$ Emulgen 911), and this content was recorded with a HITACHI U-2000 spectrophotometer according to the method of Omura and Sato. ${ }^{17)}$ Aminopyrine $N$-demethylase activity was measured by the determination of formaldehyde formation according to the method of Nash. ${ }^{18)}$ Aniline $p$-hydroxylase activity was determined by the method of Imai et $a l .{ }^{19)}$ To determine the inhibitory effect of 4-CBP on benzphetamine and dimethylnitrosamine $N$-demethylase activities in vitro, the compound was dissolved in a minimal volume of dimethyl sulfoxide and added to the assay medium at various concentrations. The protein concentration was estimated by the method of Lowry et al. ${ }^{20)}$ using bovine serum albumin as a standard.

SDS-PAGE and Immunoblot Analysis Microsomes obtained from control and 4-CBP-treated rats were solubilized in sodium dodecyl sulfate (SDS) and resolved by polyacrylamide gel $(10 \%, \mathrm{w} / \mathrm{v})$ electrophoresis according to the method of Laemmli. ${ }^{21)}$ Antigenic components reactive with polyclonal antibodies raised against various $\mathrm{P} 450$ species (CYP2B1, 2E1, 3A2, 2C11, and 2C12) were visualized with 4-chloro-1-naphthol in the presence of $0.006 \%$ hydrogen peroxide and peroxidase-labeled anti-gout IgG in $0.05 \mathrm{~m} \mathrm{Na}, \mathrm{K}$ phosphate buffer ( $\mathrm{pH}$ 7.4). Semiquantification of the bands was assayed using a computer imaging analysis system (MCID, Imaging Research Inc., Ontario, Canada).

Statistical Analysis Means of values were confirmed using a Student two-tailed $t$ test. Values were considered significantly different from the controls at $p<0.05$.

\section{RESULTS AND DISCUSSION}

To elucidate the induction response of hepatic P450 content by 4-CBP, we first examined the dose-related effect of 4CBP on microsomal P450 content in male and female rats. Rats were treated i.p. with 4-CBP at doses ranging from 0.10 to $0.80 \mathrm{mmol} / \mathrm{kg}$ for a single administration. No toxic manifestation was observed after the administration of this chemical. Figure 1 shows the structural formula of 4-CBP used in this study and the result of the dose-dependent effect on P450 content. As shown in Fig. 1A, 4-CBP significantly increased the P450 content at the lowest dose examined and produced a dose-dependent increase of P450 up to the dose of $0.40 \mathrm{mmol} / \mathrm{kg}$ to about 2.0 -fold of the control male rats, and then decreased with increasing $4-\mathrm{CBP}$ to $0.80 \mathrm{mmol} / \mathrm{kg}$. The result obtained in female rats under similar experimental conditions is also shown in Fig. 1B. Similarly, 4-CBP increased P450 content in a dose-dependent manner up to the dose of $0.40 \mathrm{mmol} / \mathrm{kg}$. We have reported that non-chlorinated benzylpyridine induces $\mathrm{P} 450$ content in a dose-related manner up to the dose of $0.80 \mathrm{mmol} / \mathrm{kg}$ in both sexes. ${ }^{10)}$ However, as shown in Fig. 1, 4-CBP fails to produce P450 induction at higher doses, suggesting that pyridine substituted with a chlorinated benzyl moiety may affect the differential induction response in rat liver.

Figure 2 shows a dose-response effect of 4-CBP on aminopyrine $N$-demethylase and aniline $p$-hydroxylase activities. Interestingly, as shown in Fig. 2A, we did not observe a dose-dependent increase in either enzyme's activities after treatment with 4-CBP. The administration of 4-CBP at the lowest dose examined $(0.10 \mathrm{mmol} / \mathrm{kg})$ resulted in a signifi-
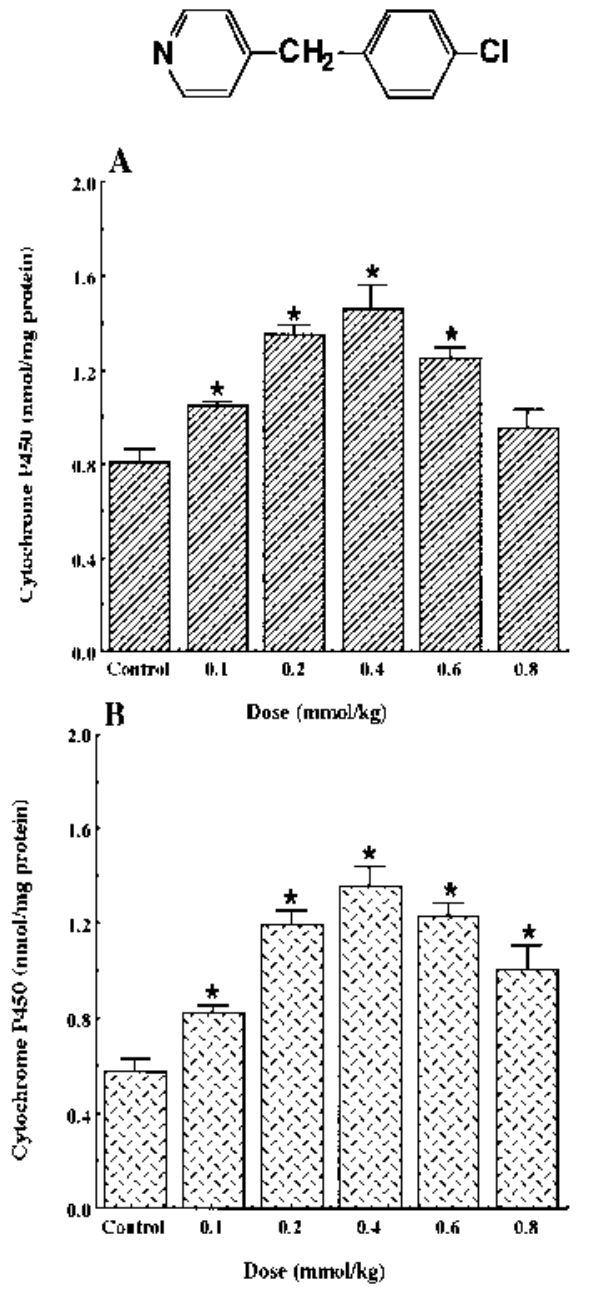

Fig. 1. Dose-Response Effect of 4-(4-Chlorobenzyl)pyridine (4-CBP) on Cytochrome P450 Content in Male (A) and Female (B) Rats

Rats were treated i.p. with $4-\mathrm{CBP}$ at doses ranging from $0.10 \mathrm{mmol} / \mathrm{kg}$ to $0.80 \mathrm{mmol} / \mathrm{kg}$ for a single administraiton, and the animals were killed $24 \mathrm{~h}$ after the treatment. Each value is the mean \pm S.D. of three to four rats. Other experimental methods were described in Materials and Methods. * Significantly different from control groups; $* p<0.05$.

cant increase in both aminopyrine $N$-demethylase and aniline $p$-hydroxylase activities, to about 2.1- and 1.6-fold of the control male rats, respectively, and then gradually decreased by $0.80 \mathrm{mmol} / \mathrm{kg}$ dose. At $0.80 \mathrm{mmol} / \mathrm{kg}$, 4-CBP markedly inhibited both enzyme activities to about 43 and $57 \%$ of the control levels, irrespective of their significant increase in P450 content (Fig. 1A). In females, both enzyme activities reached a maximum at $0.20 \mathrm{mmol} / \mathrm{kg}$, to about 1.8 - and 2.9 fold that of the controls, respectively. However, depending on the dose of 4-CBP, these mono-oxygenase activities were markedly inhibited. We have reported that 4-benzylpyridine produced a sex-dependent increase in these two enzyme activities in a time-dependent manner. ${ }^{10)}$ Our present data (Figs. 1,2 ), together with our previous paper, ${ }^{10)}$ suggests that methane with two hetero aromatic moieties is likely to be a minimal structural component for producing this sex-related induction response.

Induced levels of P450 species (CYP2B1, 2E1, 3A2, $2 \mathrm{C} 11$, and 2C12) in microsomes from 4-CBP-treated male and female rats were also examined. Figure 3 shows the typical results of an immunoblot analysis carried out on micro- 

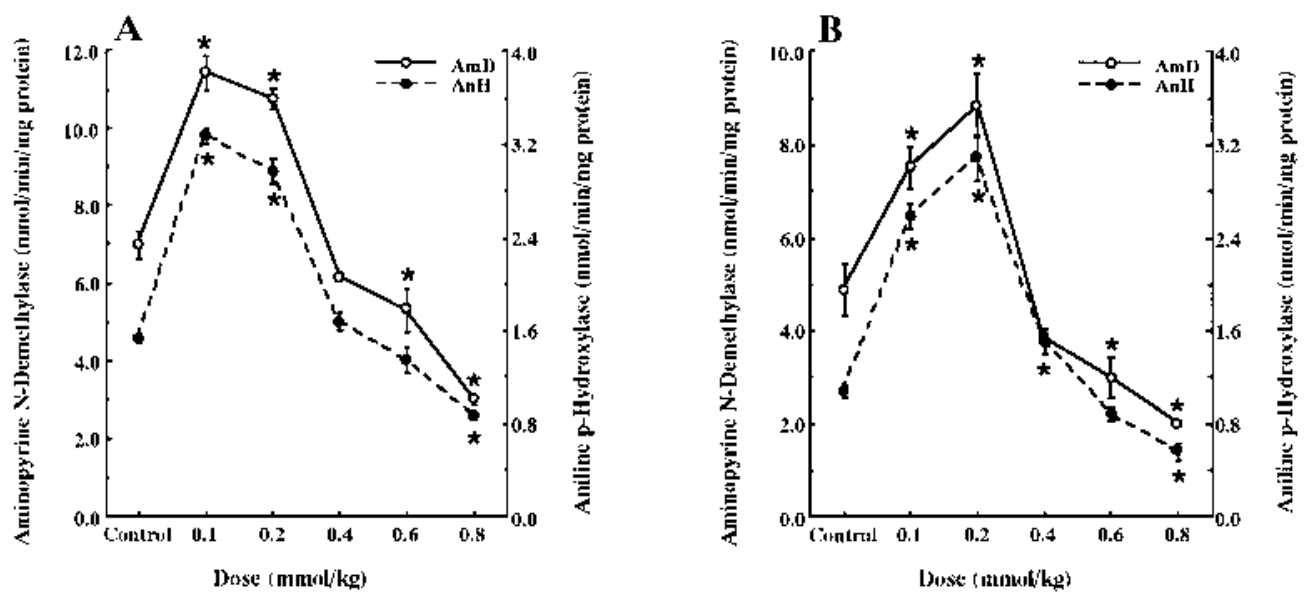

Fig. 2. Dose-Response Effect of 4-(4-Chlorobenzyl)pyridine on Aminopyrine $N$-Demethylase and Aniline $p$-Hydroxylase Activities in Male (A) and Female (B) Rats

Other experimental methods were the same as described in Fig. 1. AmD, aminopyrine $N$-demethylase activity; AnH, aniline $p$-hydroxylase activity. * Significantly different from control groups; $* p<0.05$

Table 1. Levels of CYP2B1, 2E1, 3A2, 2C11, and 2C12 Species in Liver Microsomes of Rat Treated with 4-(4-Chlorobenzyl)pyridine

\begin{tabular}{|c|c|c|c|c|c|c|c|c|}
\hline & \multicolumn{2}{|c|}{ CYP2B1 } & \multicolumn{2}{|c|}{ CYP2E1 } & \multicolumn{2}{|c|}{ CYP3A2 } & \multirow{2}{*}{$\begin{array}{c}\text { CYP2C11 } \\
\text { Male }\end{array}$} & \multirow{2}{*}{$\begin{array}{c}\text { CYP2C12 } \\
\text { Female }\end{array}$} \\
\hline & Male & Female & Male & Female & Male & Female & & \\
\hline Control & 100 & 100 & 100 & 100 & 100 & 100 & 100 & 100 \\
\hline 0.1 & 393 & 367 & 245 & 278 & 268 & 198 & 98 & 114 \\
\hline 0.2 & 568 & 692 & 218 & 295 & 279 & 412 & 115 & 89 \\
\hline 0.4 & 498 & 583 & 189 & 317 & 315 & 516 & 87 & 124 \\
\hline 0.6 & 417 & 521 & 127 & 196 & 458 & 697 & 95 & 98 \\
\hline 0.8 & 398 & N.D. & 74 & 81 & 681 & 474 & 115 & 132 \\
\hline
\end{tabular}

Each blot was calculated by MCID, and the extent of blots for each P450 isoform is represented as a \% of the control. N.D.; not determined.

somes from the 4-CBP-treated male and female rats. Table 1 also illustrates the dose-response effect of this chemical on the induction of CYP2B1, 2E1, 3A2, 2C11, and 2C12 in male and female rats. As shown in Fig. 3, the induction of CYP2B1 reached a maximum at $0.20 \mathrm{mmol} / \mathrm{kg}$; however, this activity gradually declined with a dose increase up to $0.80 \mathrm{mmol} / \mathrm{kg}$. In females, a CYP2B1 increase was also induced by 4-CBP treatment, but 4-CBP failed to increase CYP2B1 at the highest dose examined. The induction of CYP2E1 in male and female rats was also observed after the administration of 4-CBP (Fig. 3). With respect to the induction of CYP2B and 1A species by pyridine-containing compounds, we have shown that 4-benzylpyridine induces both CYP2B1/2 and 1A1/2 dose-dependently. ${ }^{10)}$ Additionally, we proposed that those compounds having aromaticity and which cannot take a coplanar structure or do not have coplanarity predominantly induce CYP2B $1 / 2{ }^{11)}$ On the basis of these findings, we examined whether 4-CBP is able to induce CYP1A1; however, we did not observe the induction of a CYP1A1 isoform after treatment with 4-CBP (unpublished observation). Magdalou et al. have shown that 1-benzylimidazole fails to displace benzo[ $a]$ pyrene from the Ah-receptor; however, they suggest that the compound could bind to the receptor with low efficiency. ${ }^{9)}$ These findings, ${ }^{9-11)}$ together with our present data (Fig. 3, Table 1), suggest that a halogenated benzyl moiety would be an indispensable structure for the induction of CYP2B1, as well as steric hindrance due to the halogen atoms, which could not take a coplanarity.

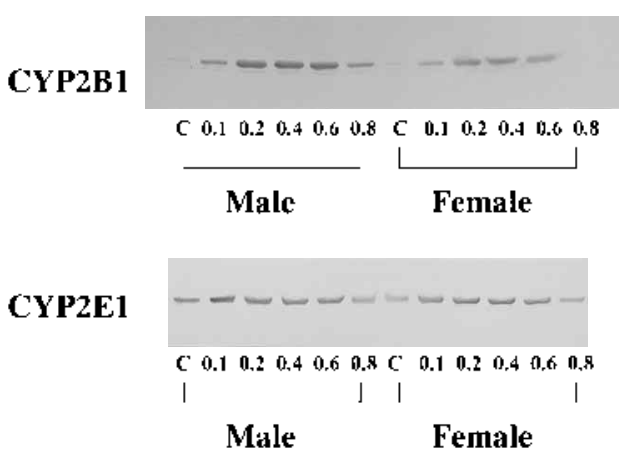

Fig. 3. Immunoblot Analyses for CYP2B1 and $2 \mathrm{E} 1$ in Microsomes from 4-(4-Chlorobenzyl)pyridine-Treated Male and Female Rats

Microsomal fractions were pooled and used for this experiment. Ten micrograms of pooled microsomal protein was loaded onto SDS-PAGE and transferred to a nitrocellulose membrane. The bands were identified by developing the peroxidase reaction with a mixture of 4-chloro-1-naphthol and hydrogen peroxide in $50 \mathrm{~mm}$ sodium potassium phosphate buffer ( $\mathrm{pH}$ 7.4). Other experimental methods were the same as described in Fig. 1.

In turn, the regulation of CYP2E1 expression has been proposed at several different molecular levels: transcriptional activation, mRNA stabilization, increased translation of mRNA, and inhibition of protein degradation because of protein stabilization. ${ }^{22,26)}$ In this respect, Eliasson et al. revealed that stabilization and protection from the destruction of CYP2E1 were provided by its inducers. ${ }^{23)}$ Kocarek et al. have suggested that the secondary structure contributed by the CYP2E1 mRNA $5^{\prime} \mathrm{UTR}$ is at least partially responsible for 
the inefficient translation of this RNA, while the $3^{\prime}$ UTR appears to be important for protecting CYP2E1 mRNA from RNase activity associated with the translation machinery. ${ }^{28)}$ Additionally, Kim and Novak reported that the elevation of CYP2E1 protein by nitrogen- and sulfur-containing heterocycles were associated with proportional decreases in CYP2E1 poly $(\mathrm{A})^{+}$RNA levels, suggesting that there is a relationship between the induction of CYP2E1 and mRNA stability. ${ }^{29)}$ As listed in Table 1, 4-CBP increased CYP2E1 protein at various doses except for a high dose administration. All of these findings, ${ }^{22-29)}$ together with our findings (Table 1), suggest that the increase in CYP2E1 protein by 4-CBP administration can be ascribed to the prevention of CYP 2E1 degradation, and perhaps to mRNA stabilization. However, further detailed study will be needed. 4-CBP did not affect sex-specific isoforms at any doses (Table 1).

It has been well known that many imidazole-containing compounds are able to inhibit drug metabolizing enzyme activity when added in vitro to the assay medium. ${ }^{30,31)}$ We have shown that 4- and 3-benzylpyridines inhibited aminopyrine $\mathrm{N}$-demethylase activity in vitro, depending on the concentration and position of the benzyl moiety linked to the pyridine ring. ${ }^{10)}$ Additionally, we have reported that 4-phenylalkylpyridines (chain length of $0-5,7,9$, and 11) also inhibit aminopyrine $N$-demethylase activity in vitro in a chain length-dependent manner. ${ }^{13)}$ Because aminopyrine $N$ demethylase and aniline $p$-hydroxylase are catalyzed by CYP2B1/2C11 and CYP1A2/2E1, respectively, we investigated further implications of $\mathrm{P} 450$ species involved in the inhibition of drug-metabolizing enzymes in vitro. Since benzphetamine $\mathrm{N}$-demethylase ${ }^{32)}$ and dimethylnitrosamine $\mathrm{N}$ demethylase $^{22)}$ are used as marker enzyme activities for CYP2B1 and CYP2E1, respectively, we examined the inhibitory effect of 4-CBP on these catalytic properties. As shown in Fig. 4, the addition of 4-CBP at a final concentration ranging from $10^{-5}$ to $10^{-4} \mathrm{M}$ in the benzphetamine $N$ demethylase assay medium, markedly inhibited in a concentration-dependent manner, by about $30 \%$ and $10 \%$, respectively (open circle). In contrast, there was no concentrationdependent loss of dimethylnitrosamine $N$-demethylase activity (closed circle, $>95 \%$ of the control at $10^{-4} \mathrm{M}$ ). It has been accepted that the inhibitory mechanism on drug metabolism is believed to be the result of high-affinity binding of the compound to the heme moiety of the cytochrome P450 molecule. ${ }^{33)}$ Those findings, ${ }^{33)}$ together with our results (Fig. 4), suggest that 4-CBP has higher affinity with the CYP2B1 molecule than the CYP2E1 in vitro.

In conclusion, the present study has revealed that 4-CBP produces the induction and inhibition of $\mathrm{P} 450$ and its molecular species, depending on the dose level. The in vitro inhibitory experiment has revealed that benzphetamine $N$ demethylase activity was markedly inhibited by the addition of 4-CBP in a concentration-dependent manner. Thus, our results suggest that substituted pyridine compounds having a chlorine atom at the 4-position of the benzyl moiety serve as an underlying mechanism in the induction and inhibition of P450 species, especially CYP2B1.

Acknowledgements This study was supported in part by grant from the Ministry of Education, Science, Sports and Culture of Japan (12771468).

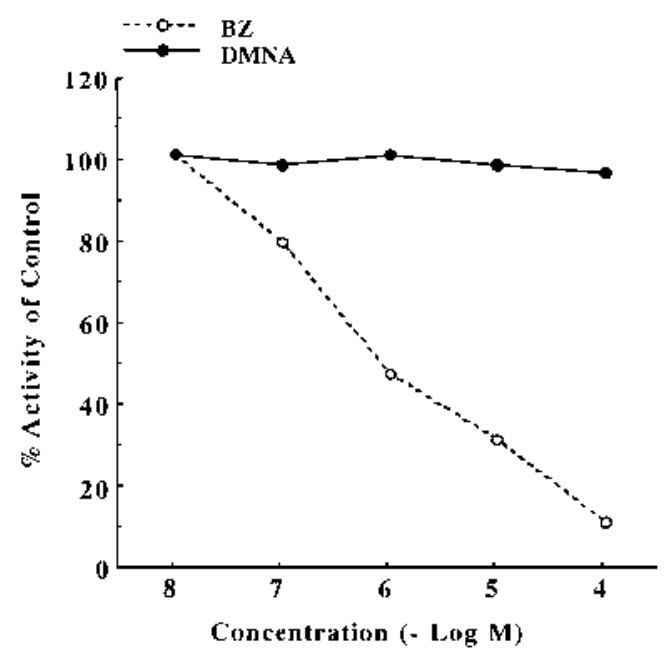

Fig. 4. Inhibitory Effect of 4-(4-Chlorobenzyl)pyridine on Benzphetamine and Dimethylnitrosamine $N$-Demethylase Activities in Vitro

4-(4-Chlorobenzyl)pyridine was dissolved in a minimal volume of dimethyl sulfoxide and diluted with water. The final concentration of dimethyl sulfoxide in the assay medium did not exceed $0.015 \%(\mathrm{v} / \mathrm{v})$. A solution of the compound was added to each assay at the final concentrations indicated in the figure. The microsomal suspension used was prepared from phenobarbital-pretreated $(80 \mathrm{mg} / \mathrm{kg} / \mathrm{d}$ for 2 consecutive days) for benzphetamine $N$-demethylase, and from pyridine-pretreated $(100 \mathrm{mg} / \mathrm{kg} / \mathrm{d}$ for 4 consecutive days) for dimethylnitrosamine $N$-demethylase activities, respectively. The cytochrome P450 content of phenobarbital- and pyridine-pretreated suspensions was $1.47 \pm 0.077 \mathrm{nmol} / \mathrm{mg}$ protein and $0.83 \pm 0.097 \mathrm{nmol} / \mathrm{mg}$ protein, respectively. Each value represents the percent of control benzphetamine, and dimethylnitrosamine $N$ demethylase activities were $5.86 \pm 0.108 \mathrm{nmol} / \mathrm{min} / \mathrm{mg}$ protein and $6.05 \pm 0.078 \mathrm{nmol} /$ $\mathrm{min} / \mathrm{mg}$ protein, respectively. BZ, benzphetamine $N$-demethylase activity; DMNA, dimethylnitrosamine $N$-demethylase activity.

\section{REFERENCES}

1) Gonzalez F. J., Pharmacol. Rev., 40, 243-288 (1988).

2) James M. O., Toxicology, 50, 269-281 (1988).

3) Leslie C., Reidy G. F., Stacey N. J., Biochem. Pharmacol., 37, 41774181 (1988).

4) Papac D. I., Franklin M. R., Drug Metab. Dispos., 16, 259-264 (1988).

5) Hostetler K. A., Wrighton S. A., Molowa D. T., Thomas P. E., Levin W., Guzelian P. S., Mol. Pharmacol., 35, 279-285, (1989).

6) Franklin M. R., Toxicol. Appl. Pharmacol., 111, 24-32 (1991).

7) Franklin M. R., Moody D. E., Drug Metab. Dispos., 20, 726-729 (1988).

8) Manning B. W., Franklin M. R., Xenobiotica, 22, 1395-1402 (1992).

9) Magdalou J., Totis M., Boiteux-Antoine A., Fournel-Gigleux S., Siest G., Schladt L., Oesch F., Biochem. Pharmacol., 37, 3297-3304 (1988).

10) Kobayashi Y., Matsuura Y., Kotani E., Iio T., Fukuda T., Aoyagi T., Tobinaga S., Yoshida T., Kuroiwa Y., Biochem. Pharmacol., 43, 2151-2159 (1992).

11) Kobayashi Y., Matsuura Y., Kotani E., Fukuda T., Aoyagi T., Tobinaga S., Yoshida T., Kuroiwa Y., J. Biochem. (Tokyo), 114, 697-701 (1993).

12) Kobayashi Y., Yamamoto T., Okui E., Kotani E., Yoshida T., Kuroiwa Y., Jpn. J. Toxicol. Environ. Health, 42, 468-478 (1996).

13) Kobayashi Y., Yoshida T., Kotani E., Matsuura Y., Egawa H., Aoyagi T., Imaoka S., Funae Y., Tobinaga S., Kuroiwa Y., Xenobiotica, 25, $779-789$ (1995).

14) Kobayashi Y., Yoshida T., Kotani E., Aoyagi T., Kuroiwa Y., Tobinaga S., Biochim. Biophys. Acta, 1200, 11-18 (1994).

15) Yoshida T., Kobayashi Y., Masuko T., Hashimoto Y., Kuroiwa Y., Toxicol. Lett., 76, 145-153 (1995).

16) Kobayashi Y., Ohshiro N., Okui E., Tokuyama S., Yoshida T., Yamamoto Y., Xenobiotica, 30, 683-692 (2000).

17) Omura T., Sato R., J. Biol. Chem., 239, 2370-2378 (1964)

18) Nash T., Biochem. J., 55, 416-421 (1953).

19) Imai Y., Ito A., Sato R., J. Biochem., 60, 417-428 (1966).

20) Lowry O. H., Rosebrough N. J., Farr A. L., Randall R. J., J. Biol. 
Chem., 193, 265-275 (1951).

21) Laemmli U. K., Nature (London), 227, 680 - 685 (1970).

22) Song B. J., Veech R. L., Park S. S., Gelboin H. V., Gonzalez F. J., J. Biol. Chem., 264, 3568-3572 (1989).

23) Eliasson E., Johansson I., Ingelman-Sundberg M., Biochem. Biophys. Res. Commun., 150, 436-442(1988).

24) Song B. J., Gelboin H. V., Park S. S., Yang C. S., Gonzalez F. J., J. Biol. Chem., 261, 16689-16697 (1986).

25) Kato R., Yamazoe Y., "Cytochrome P450," ed. by Schenkman J. B., Greim H., Handbook of Experimental Pharmacology, Springer-Verlag, Berlin, Heidelberg, Germany, 1992, pp. 447-459.

26) Hu Y., Ingelman-Sundberg M., Lindros K. O., Biochem. Pharmacol., 50, 155-161, (1995).

27) Wrighton S. A., Thomas P. E., Molowa D. T., Hanui M., Shively J. E., Mains S. L., Watkins P. B., Parker G., Mendezpicon G., Levin W.,
Guzelian P. S., Biochemistry, 25, 6731—6735 (1986).

28) Kocarek T. A., Zangar R. C., Novak R. F., Arch. Biochem. Biophys., 376, 180-190 (2000)

29) Kim S. G., Novak R. F., Toxicol. Appl. Pharmacol., 120, 257-265 (1993).

30) Laignelet L., Narbonne F. J., Lhuguenot J. C., Riviere J. L., Toxicology, 59, 271-284 (1989).

31) Wilkinson C. F., Hetnarski K., Denison M. S., Guengerich F. P., Biochem. Pharmacol., 32, 997-1003 (1983).

32) Kedzie K. M., Balfour C. A., Escobar G. Y., Grimm S. W., He Y.-A., Pepperl D. J., Regan J. W., Stevens J. C., Halpert J. R., J. Biol. Chem., 266, 22515-22521 (1991).

33) Ritter J. K., Franklin M. R., Drug Metab. Dispos., 15, 335-343 (1987). 